\title{
Decolonising Biblical Trauma Studies: The Metaphorical Name Shear-jashub in Isaiah 7:3ff Read Through a Postcolonial South African Perspective
}

\author{
LiZa Esterhuizen (University OF Pretoria)
}

\begin{abstract}
Anyone reading the Bible will attest that Biblical scriptures preserve a collection of struggles, trauma, and hardship in their ancient communities - the same trauma markers that many South Africans can attest to. On the same continuum, anyone who is reading the book of Isaiah, are confronted with not only a difficult book but also a difficult prophet. Isaiah did not in Isaiah 7:3ff only address his prophetic utterances at the King as an individual, but also at the people of Judah as a collective group and he did so through the metaphorical namegiving of his son "Shear-jashub." The fear of imperialism and oppression was a reality, as it would later be in apartheid South Africa. The reading of Isaiah 7:3ff from a postcolonial perspective aims to provide a decolonised biblical trauma lens that would create an understanding of a decolonised reader in a postcolonial South Africa.
\end{abstract}

KEYWORDS: Trauma; Isaiah; Biblical trauma; Children; postcolonial studies, Decolonising

We are wounded people...

We all stand in need of healing.

Desmond Tutu

\section{A INTRODUCTION}

Professor Willie Wessels was my supervisor and mentor and friend when I did my PhD studies at the University of South Africa. Therefore, it is a great honour to contribute to this festschrift celebrating his life and academic contribution. Many of his academic research focused on justice and leadership and it just seemed fit to write an article on decolonising biblical trauma studies with reference to Isaiah 7:3ff, to correlate to his study field.

* Submitted: 15/08/2018; peer-reviewed: 03/01/2019; accepted: 09/01/2019. Liza Esterhuizen, "Decolonising Biblical Trauma Studies: The Metaphorical Name Shearjashub in Isaiah 7:3ff Read Through a Postcolonial South African Perspective," Old Testament Essays 31 no. 3 (2018): 522-533. DOI: https://doi.org/10.17159/23123621/2018/v31n3a7. 
The word colonialism has become the proverbial 'albatross around the neck' of the new South Africa. No wonder that on the continuum of discussion, some debaters want to rip the traces of colonialism from the foundations of history, while others defend and value the legacy thereof. On both sides of the spectrum, emotional wounds are inflicted, and psychological scars become the symbol of the colonial discourse. For the biblical scholar, colonialism in its many forms produces an array of religious and theological challenges. Themes of displacement, disobedience, and disbelief that were part of the lives of the people in the Old Testament, are familiar to biblical scholars. These themes are pertinent in the time of Isaiah and the Judean nation, long before it became part of the South African postcolonial and biblical trauma dialogue. The biblical text is often dualistic, on the one hand conveying compassion and tolerance and on the other providing justification for war, invasion of land and suffering.

\section{B THE MEANING OF TRAUMA}

All of us, at some point in our lives, experience suffering and trauma. The question can therefore rightfully be asked: Why do trauma and suffering have such a great impact on human life? The answer is quite simple, because it is part of being human from the beginning of time. For some people the impact of the trauma is to a greater extent than it is for others. Be it as the result of difficult circumstances and accidents or for being from a certain race, group, gender, culture or different religious belief. Even the terminology for trauma derives from ancient times with the origin of the word in Greek, meaning 'wound'. History books are laced with records detailing the impact of suffering and trauma. Much has been written on the topic of trauma theories and studies and the impact of traumatic events on society as a whole. Individual trauma was the offset point that started the interest in trauma studies. Only later, historical events such as war, epidemics, and terrorism gained enough interest to be studied as mass or collective trauma.

The phenomenon of trauma studies is a fairly new psychological concept finding its origins in the ground-breaking work of Jean-Martin Chardot and Sigmund Freud in the latter part of the twentieth century. Trauma was initially seen as a being a visible bodily wound that was inflicted on a person, but Freud's research changed this understanding as he describes trauma also as a psychological wound inflicted on the mind. Since then many types of research have been done where psychologists have identified a distinct type of suffering, and how it influences the way and ability that an individual and community cope with these traumatic circumstances. The research showed that prolonged exposure to suffering leads to trauma. Communal suffering is seen as collective trauma that is experienced by a group or a community. Erikson (1995:5) defines collective trauma as 'a blow to the basic tissues of social life that damages the bonds attaching people together and impairs the prevailing sense of community.' and Shamai (2016:17) concurs when stating that 'trauma goes beyond loss and 
damage, but it extends to the entire collective of a group or unit.' Rambo (2010:3) writes that trauma is 'suffering that remains'. Anyone reading the Bible will attest that Biblical scriptures preserve a collection of struggles, trauma, and hardship in their ancient communities and with their relationship with Yahweh. Biblical scholars have recognised the need to read the biblical text with the help of trauma theories to gain better insight and knowledge of some of the most painful and traumatic texts in the Bible. To underline this need to read biblical texts with the help of a trauma perspective Boase and Frechette (2016:2) state that biblical interpreters recognise the 'multiple facets of trauma' within the text but that they also recognise that there are survival and coping mechanisms embedded in the text. Rambo (2010:4) is of the opinion that biblical scholars 'have always been engaged with the perennial question of suffering.'

\section{COLONISATION AND APARTHEID}

In line with the same notion, a lot has been said, discussed and deliberated about apartheid and the ramifications of the atrocities that formed part of the South African landscape. The democratic elections of the $26^{\text {th }}$ April 1994 did not become a magic wand that would rectify the sins of the past. The new South Africa faced a magnitude of challenges to create what everyone hoped for, viz. a rainbow nation. Physical, emotional and psychological wounds ran deep and as a remedy for the suffering, the Truth and Reconciliation Commission was established as a platform for catharses and understanding. In the opening address of the Truth and Reconciliation Commission, Desmond Tutu (1999:4) remarked 'Every South African has to some extent been traumatised.' The speech by Tutu expressed a profound truth and Leys (2012: viii) writes that after the fall of apartheid, the historical context in South Africa became even more 'entangled' and 'complex' than before. After twenty-four years, this proclamation of Leys still rings true and the situation that South Africa finds itself in today requires reflection on the past and a future pull. Oxford dictionary of English (2010: 190) defines colonisation as:

'an ongoing process of control by which a central power dominates the surrounding land and its components. The term is derived from the Latin word colere, which means "to inhabit".

Therefore, it is important to investigate not only the decolonisation of trauma studies but also the decolonising of biblical trauma studies to address the new challenges and opportunities that face South Africans as a nation today. This paper will discuss a possible way to decolonise biblical trauma studies and how the reading of Isaiah 7:3ff, through a decolonised biblical trauma lens, and a postcolonial perspective, can give the insight to move toward collective healing as a communal nation. The notion of hope will be discussed with reference to Shear-jashub and the trope of the returning remnant not only as an embodiment but also as an emotional concept for a postcolonial perspective. 
Esterhuizen, "Decolonising Trauma," OTE 31/3 (2018): 522-533 525

\section{WHY DECOLONISE TRAUMA AND BIBLICAL TRAUMA STUDIES?}

The ground-breaking essay of Rothberg (2008:224) remarked that as long as trauma theories and studies stayed 'tied to a narrow Eurocentric framework, it distorts and becomes inclusive of singular events.' In his essay, he refers to the Holocaust as such a singular event because it is set in a specific time frame and it played out within a specific period in time. And it is precisely here that the conundrum lies. Most attention in trauma studies has been focused on events that took place within Europe or the United States of America and the lack of interest in the non-Western world is therefore not a surprise. There are, though many scholars who feel that trauma is a Euro-American phenomenon that is not part of the rest of the world. Postcolonial trauma is not a singular event but ongoing into the present and in a way also shaping how the future will play out. As trauma is so often described as a 'frightening event outside of the ordinary' according to Ward (2015:9), this definition is not workable for a South African post-apartheid situation that is not always related to a specific event with a conclusive before and after. Visser (2015:9) explains that the reason why trauma studies need to be decolonised is that postcolonial trauma is a prolonged and often prolonged process over a period of time that can be alluded to colonialism. It is of interest to note that Cooppan $(2012: 47)^{1}$ states that colonialism and apartheid can be defined as a traumatic history because it is not only a once off occurrence but span over many years. Firstly, it was marked by the devastating effect that it had on the emotional wellbeing of individuals, the collective group and the society at large. Secondly, the repeating of these experiences over a period of time and the 'ghosting' of the post-apartheid and postcolonialism present. Finally, the collectiveness of these prolonged effects on specific individuals became the collective trauma of a specific group. The abovementioned aspects of trauma history in South Africa hold and suggest the same biblical trauma properties for the people of Judah in Isaiah 7 and the metaphorical name-giving if Isaiah 7:3ff. The prolonged and continuous exposure to threats of war, the threat of well-being and possibility of an invasion of land and subsequent exile, contains similar emotional and physical burdens that the impact of colonialism had and still reverberate in a post-apartheid South Africa.

Since 2008, there have been an increasing number of postcolonial scholars who realised the need to decolonise trauma theory and the need to rethink the legacies of trauma and violence that were left behind by colonialism. On this notion, Visser (2015:15) declares that there is a movement by many scholars to discarded the Freudian psychoanalysis approach towards a more sociological and historical perspective where the traumatic histories of the colonised groups are at the fore to allow cultural aspects as well. I do not necessarily agree with the discarding of the historical concept of trauma study,

\footnotetext{
${ }^{1}$ This is a summation of the work of Cooppan, V (2012: 47-53) on postcolonial trauma.
} 
because I believe there is validity in the identification of the trauma stressors and the clinical symptoms of trauma, which are important for the reading of biblical text through a trauma lens. However, I do concur with postcolonial scholars such as Visser (2016), Najita (2016), and Craps and Buelens (2008) that the integration of other social science fields such as cultural and traditional studies are vital if trauma theory is to be applicable to non-western nations. Until now, only the one-sided scope from a Euro-American centric perspective is used and that needs to be decolonised. Visser (2015:15) further states that if trauma theory makes connections with other fields of study such as sociology and anthropology, 'trauma would not only be coherent of cause and effect, but it may affirm a sense of belonging, kingship and mutual trust for the individual and the community.' These connections with other fields of study remain essential and, in a way, it already exists in biblical trauma studies where a historical and literal understanding are an essential part of the exposition of the text. For it to be applicable in a postcolonial South African reading, it has to understand and take the colonial aspects within a South African context into consideration. In the words of Allan Boesak in Boesak and Hansen (2010:72) who wrote 'we need a process of "decolonization", a process that will help us undo the domestication of God and the writings of the Old Testament that has proved so harmful in the history of western Christianity.' It might be time that we as biblical scholars realise that we need to be sensitive to the cultural bias and that the non-West should not be viewed as less civilized and in dire need to be enlightened or rescued. Martinez-Falquina (2016:840) makes the summation that 'a response to trauma from a respectful cognition of culturally specific spiritual and religious perspectives, analogous to the recognition of historical, national, and ethnic diversification, is necessary for a postcolonial theory of trauma to be fully decolonised.'

It should further be noted that to renew our thinking and understanding is an opportunity to grow as biblical scholars. It is time to be honest that Germany or the West for that matter, can no longer be seen as the dominant force for theological thinking and that the connections we make when working with text need to play out within the space we are, namely land, culture, languages, race, and beliefs. A postcolonial reading of the biblical text creates new opportunities for biblical studies to work alongside other disciples such as psychology, sociology and also anthropology. Biblical scholars have been open-minded to integrate multiple-disciplines in their research endeavours, but it seems that postcolonialism battles to get an academic voice and cooperation when it comes to the dismantling of colonialism and address issues such as nation, race, captivation, and slavery. On this issue, Sugirtharajah (2006:17) postulates that 'the greatest single aim of postcolonial biblical studies is to situate colonialism at the core of the Bible and biblical interpretation.' 
Esterhuizen, "Decolonising Trauma,” OTE 31/3 (2018): 522-533 527

\section{E A DECOLONISED READING OF ISAIAH 7:3FF, SHEAR- JASHUB, THROUGH A POSTCOLONIAL TRAUMA PERSPECTIVE}

The recent interest of scholars in biblical trauma studies instils the belief that it is a new historical moment in the field of biblical thought. Even if this is the case, the South African cultural and social reality is more complicated and challenging in relation to Eurocentric trauma studies. Biblical trauma studies must adhere to the call to read the biblical text from a South African postcolonial perspective to address a fundamental need in this regard. This is indeed a new prospect in the field of biblical trauma studies.

A question that can rightfully be asked is, can the reading perspective that pertains to the term 'postcolonial' be applicable to the metaphorical name of Shear-jashub in Isaiah 7:3ff? The answer lies according to Carter (2009:69) in the meaning of the prefix 'post'. Carter (2009:69) further explains:

The prefixed preposition reflects the location of much contemporary discussion that wrestles with the continuing legacy of post-Enlightenment, European colonialism, the post-40s period of decolonisation or the official relinquishing of formal control by colonial power, the emergence of independent nations and the rise of newer forms of cultural imperialism.

Still, clarity around the word 'post' seems to elude most critical scholars as this prefix as a term encapsulates historical and theoretical nuances. The diasporic nature of postcolonialism contains influences from other theories such as psychology, feminist studies, philosophy, anthropology and political science. As with trauma and trauma studies, postcolonial biblical interpretation has been scrutinized, discussed and re-interpreted over the years and just like trauma studies, postcolonial approaches only gain interest in the academic world in the 1980s. The first investigative work on postcolonialism was done by Said (1979) where he questioned and also criticised European and American lack of knowledge of the Orient and East. Based on the work of Said, Bhabha (1994) and Spivak (1999) both studied the 'minorities' of the Third World counties and the liberation movement from a postcolonial perspective. Sugirtharajah (2012:13) writes that postcolonialism has 'functioned as a political indicator and a literary critical tool. It is about the impact created by western colonization on individuals, communities, and cultures.' The postcolonial definition given by Dube (2000:15) states that the word has been coined to describe 'the history of empire-building, beginning the whole process of colonialism, an ensuing struggle for independence, then the attainment of independence and then the founding of neo-colonist realities. The whole postcolonial process accentuates the ongoing connection between past and present.' Maier (2013:12) underlines the struggle to define postcolonial studies as 'approaching the end of the first decade of the twenty-first century, postcolonial studies describe a burgeoning field of ideological-critical inquiry, which can hardly be defined anymore.' Just 
like trauma, postcolonialism should serve as a tool or lens to aid biblical scholars in the reading of the biblical text. Therefore, the name-giving in Isaiah 7:3ff should be read with discernment through postcolonial perspective taking history, trauma and the present into consideration.

History matters and according to Kim (2008: 118) this does not only apply to the history of the composition of a book like Isaiah but also to that of the main characters that form the historical corpus of the book. The book Isaiah represents the history and works of different imperial forces that on many levels threatened the nations of Israel and Judah. Esterhuizen (2016:69) writes that every biblical scholar who works with the text of Isaiah 7, is confronted with a multi-layered text and a third-person narrative account. The complexity of chapter 7 can only be comprehended against the backdrop of the political setting and ensuing prophecy of Isaiah.

In Isaiah 7, Judah as a minority group in comparison to an empire and possesses very little to power to defend themselves or control their destiny. A postcolonial perspective accentuates themes such as invasion, displacement, threats of exile and actual exile. These themes become intertwined with issues such as fear, helplessness, feelings of detachment, collective trauma as a group and powerlessness. The metaphorical name-giving of Shear-jashub in Isaiah 7:3ff contains themes and trauma markers that are relevant to a postcolonial trauma perspective. The historical setting of Isaiah 7 belongs to the SyroEphraimite Crisis of 735-732 BCE. The kingdom of Judah was a modest political state but there were two political conflicts that brought looming danger and threat to the kingdom of Judah. The first conflict pertains to the name-giving of Isaiah's children and the message that the names held for King Ahab and the people of Judah. The second crisis that was even more dangerous and looming, was the threatening invasion by the Assyrians under the leadership of Sennacherib in 704-701 BCE. At the time, Assyria was seen as an imperial powerhouse conquering many nations that crossed their path. As Perdue (2015:40) so rightly states 'The Assyrian Empire sought to legitimize its rule in various ways, to expand their imperial boundaries and to emphasize their superiority.' The show of power was achieved through harassment and threats to the well-being of their enemies and victims. The meeting between King Ahab and the prophet Isaiah in chapter 7, is told in the third person (Isaiah 7:3: 'Then the Lord said to Isaiah...') ${ }^{2}$ At that time, King Ahab was filled with fear and the prophet Isaiah was sent to confront the King about his disobedience to Yahweh. Isaiah was also instructed to take his young son Shear-jashub with him to meet King Ahab. The text in Isaiah 7:3 reads as follows:

\footnotetext{
${ }^{2}$ (The English Standard Version, 2001) is used for text references.
} 
'And the Lord said to Isaiah: "Go out to meet Ahab, you and Shearjashub Your son, at the end of the conduit of the upper pool on the highway to the Washer's Field"'.

The name of Isaiah's son meant 'a remnant shall return'. Blenkinsopp (2000:231) remarks that the name of the child within the text contexts, clearly caries a 'good omen' for the King and the people of Judah if they show faith in Yahweh. The latter part of the name of Isaiah's son - jashub - implies a hopeful return to Yahweh. It also embodies a metaphor of 'returning from battle' and 'survival in war'. Even though despair, war, displacement, and imperialism were looming, the name carried a metaphorical meaning of hope and salvation. This hope was embedded in the unconditional faith of the King and of the people of Judah in Yahweh.

A few aspects relating to trauma need to be considered when reading Isaiah 7:3. Being constantly bombarded with threats and danger disrupts not only the well-being of the individual but also the social fibre of an entire community. The constant exposure and waiting for something to happen, influences lives, identities, culture, social networks and the current political climate. The impending threat of war and invasion from Assyria was a constant reminder that the people of Judah could become a vassal of the Assyrians. In relation to a South African context, being a vassal of another group, race or nation can be interpreted as colonialism, even though the term colonialism was not used in the ancient Near East. Here colonialism means to be controlled and governed by another group or entity. This was something that the people of Judah could relate to. This is also something that the majority of black, Indian and coloured South Africans can relate to in apartheid South Africa. The name Shear-jashub holds a powerful and dissident metaphorical meaning as it becomes a physical and emotional communication means to convey the message from Yahweh to the King. Brown (2007:142) assumes that a metaphor of this nature is effective because it can communicate a message when a literal expression fails to do so.

Even though the historical setting of Isaiah 7:3ff belongs to a different historical setting than that of the postcolonial setting in South Africa, the metaphorical meaning of the name Shear-jashub, in Isaiah 7:3ff could be of significance in a postcolonial setting in South Africa today. Sawyer (2018:246) writes that the inclusion to read the text of Isaiah as postcolonial underlines the need to read the text from a fresh and new perspective. The trauma that was experienced in a pre and post-apartheid context in South Africa can be described as a continual social traumatic process, which leads to the creation of a collective anti-apartheid and postcolonial identity for many South Africans. Colonialism in South Africa, through the trauma that it has imparted, created a collective group identity of survival and strive and of a remnant that will sustain the collective narrative and of postcolonial hope. Visser (2016:15) states that decolonised collective trauma is a direct result of a 'sociocultural narrative' that helps to 
construct the traumatic experience. It could therefore then be said that a decolonised biblical trauma reading of Isaiah 7:3, where the adversity of apartheid are part of the body and soul of many South Africans, can perform a valuable role in the healing process that gives shape and meaning to this wounding phenomenon.

The remnant became for the Judean people a beacon of hope and a promise of Yahweh's salvation and so can it be for South Africa as a symbol and a sign of hope in a postcolonial collective South Africa. Boesak (2014:26) writes that 'there is something intensely fascinating about hope, about our deep longing for its life-giving presence in our lives. But hope is not just to fight the battle to survive; it is to fight the battle beyond survival, to secure life, not for ourselves so much as for others who are not able to fight.' The hope as described by Boesak, becomes the remnant in Isaiah 7:3ff, and the desire to survive affirms in an emphatic way our own connection to Yahweh, in the same way, that the Judean people knew that their hope was founded in their trust of Him. Boesak (2014:27) further elaborates on that when he explains that the hope placed in Yahweh, depicts divine love and compassion that equals a 'God of hope'. Hope teaches the people that a remnant will return and if they turn back to Yahweh, hope will abide, and the enemy will not succeed. On the same idea of hope, Boesak (2014:27) postulates that hope is a 'language' but that this hope should be a new language and not a language of 'colonised and crippled minds' that speak a negative language of fear, unbelief, subordination, submissiveness, doubt and anxiety. The promise of hope in Isaiah 7:3 in the metaphorical namegiving of 'a remnant shall return' can instil collective growth for a nation that is decolonised from judgment or fear to create a new collective identity of Ubuntu.

The term Ubuntu translated into English means 'people are people through other people'. The Western world might not understand the saying but in an African context this phrase has a deep religious meaning and a tremendous influence on many South Africans. Kuene (2012:1) writes that Ubuntu has a pervasive spirit of caring that individuals and communities display for one another. Paul (2009:6) states that Ubuntu is 'a corporate and communal way of life that stands in direct opposition to the hierarchical, discriminatory, separatist and systemic class warfare of apartheid.' In Isaiah 7:3, the remnant metaphor of hope helped the people of Judah to realize that a hopeless situation of becoming an Assyrian vassal could be overturned through faith and communal strength. In South Africa, Ubuntu as a hopeful communal solidarity dared to hope that a remnant of courage could turn a hopeless situation around. Amongst its most valuable attributes, there is solidarity, conformity and collective unity especially in the face of hardship and danger which are classical trauma markers in a society that needs to huddle together to handle a traumatic experience. Boase and Frechette (2016:49) make the supposition with reference to the book of Lamentations that when there is collective suffering or trauma, a collective 'solidarity and identity' is formed. Eze (2009:94) argues that Ubuntu, as a South 
African discourse is a crucial component of a post-apartheid and postcolonial nation. According to Eze (2010:96) the South African community during apartheid had a fear-related identity. A postcolonial reading of the text will articulate an appropriate social praxis encapsulating the essence of Ubuntu.

Ubuntu, as with trauma and postcolonialism, should encapsulate a perspective or lens as an aid for reading the biblical text. African philosophy such as Ubuntu can help to gain insight on the reading of the biblical text with a value base that is part of African culture and understanding. Even though Ubuntu is first and foremost an African concept, it is deemed an appropriate decolonised biblical trauma term to be utilised in a postcolonial perspective, because it embraces the 'remnant' without exclusivity. Mbiti (1990:108) clarifies the concept of Ubuntu as 'whatever happens to the individual happens to the whole group and whatever happens to the whole group, happens to the individual'. This does not, however, mean that the right of the individual is herewith taken away because the right of the individual will always remain at the fore within a specific community. When communities and the individual within a community are facing trauma such as looming war, diaspora, displacement, danger and oppression, the values of Ubuntu can become a light of hope and tolerance to cope with the onslaught of trauma. Ubuntu as a lens should encompass the history, present and the future of the Ubuntu language. The history should serve as a source to grow from. Eze (2010:162) surmises that 'Ubuntu should be seen in continuity with history, but not as the end of history, or as history itself'.

In Isaiah 7:3 the image of a child is used to convey Yahweh's message to King Ahab and the people of Judah. The use of the 'children' motive in the message is covenantal. This child imagery portrays a young and innocent child and symbolises that there is no discrimination between people and that people of all social statuses are equal before Yahweh. Ubuntu also does not segregate but through inclusivity creates a collective community. This community is equal not only in terms of being a community but also as collective group in their similarity of being hopeful. Equality before Yahweh does not entail nationality or race, but an inclusivity and understanding that everyone is Yahweh's children - everyone is a remnant, a beacon of hope in a rainbow nation.

\section{F CONCLUSION}

To develop a decolonised theory for trauma and biblical trauma that will agree with the current South African situation will not be an easy task but it holds an immense challenge for those that are interested. The aim of this paper was not to give an in-depth treatment of decolonisation of biblical trauma studies or to address the postcolonial concept in detail. The intention was rather to set the tone for further research about the topic through a brief discussion of the aspects pertaining to decolonised trauma, decolonised biblical trauma, postcolonialism, Ubuntu and the possible reading of Isaiah 7:3ff through a postcolonial biblical trauma perspective. A variety of literature was studied and cited across an array 
of disciplines such as theology, humanities, psychology, and sociology to attain a broader perspective of the concepts discussed. I believe that the biblical text overall, and especially that of Isaiah should be treated in a South African manner to adhere to the voices of a decolonised reader. Thus, there is a wide-open door for research.

\section{BIBLIOGRAPHY}

Bhabha, H.K. The location of culture. (Routledge Classics). London, New York: Routledge, 1994.

Blenkinsopp, J. Ed. Isaiah 1-39: a new translation with introduction and commentary. 1st ed. (The Anchor Bible No. Vol. 19). New York: Doubleday, 2000.

Boase, E. \& Frechette, C.G. Eds. Bible through the lens of trauma. Atlanta: Society of Biblical Literature, 2016. https://doi.org/10.2307/j.ctt1h1htfd

Boesak, A. Dare we speak of hope? searching for a language of life in faith and politics. Grand Rapids, Michigan: Eerdmans, 2014.

Boesak, A. \& Hansen, L.D. Globalisation: the politics of empire, justice and the life of faith. Stellenbosch: SUN PReSS, 2010.

Brown, J.K. Scripture as communication: introducing biblical hermeneutics. Grand Rapids: Baker Academic, 2007.

Cooppan, V. Trauma, memory, and narrative in the contemporary South African novel: essays. E. Mengel \& M. Borzaga (eds.). (Cross/cultures No. 153). Amsterdam; New York: Rodopi, 2012.

Craps, S. \& Buelens, G. "Introduction: Postcolonial Trauma Novels." Studies in the Novel 40/1 (2008): 1-12.

Erikson, K. A new species of trouble: the human experience of modern disasters. New York: W.W. Norton, 1995.

Eze, M.O. "Intellectual history in contemporary South Africa." [Online], Available: http://search.ebscohost.com/login.aspx?direct=true \&scope $=$ site $\& \mathrm{db}=\mathrm{nlebk} \& \mathrm{db}$ $=$ nlabk\&AN=997662 [2018, August 14], 2010

Kim, H.C.P. Recent research on the major prophets. A.J. Hauser (ed.). (Recent research in biblical studies no. 1). Sheffield [England]: Sheffield Phoenix Press, 2008.

Kuene, M. "Aspects of Ubuntu for biblical studies." Faithful Teaching (2012) 12:1-8.

Leys, R.. Trauma, memory, and narrative in the contemporary South African novel: essays. E. Mengel \& M. Borzaga (eds.). (Cross/cultures no. 153). Amsterdam: New York: Rodopi, 2012.

Maier, C.M. Prophecy and power: Jeremiah in feminist and postcolonial perspective. C.M. Maier \& C.J. Sharp (eds.). (Library of Hebrew Bible/Old Testament studies no. 577). London: Bloomsbury. 2013.

Martinez-Falquina, S. "Postcolonial Trauma Theory in the contact zone: Stategic representation of grief" in Edwidge Danticat's 'Claire of the sea light. 4:834-860. 2016.

Mbiti, J.S. African religions \& philosophy. 2nd rev. and enl. ed. Oxford: Heinemann. 1990.

Najita, S.Y. "Decolonizing cultures in the Pacific: reading history and trauma in contemporary fiction." (Routledge research in postcolonial literature no. 14). New York: Routledge. 2016.

Oxford dictionary of English. 3rd ed. New York: Oxford University Press, 2010. 
Paul, S.A. The Ubuntu god: deconstructing a South African narrative of oppression. Eugene: Pickwick Publications, 2009.

Perdue, L.G. Israel and Empire: a postcolonial history of Israel and early Judaism. L.G. Perdue \& C. Warren (eds.). London: Bloomsbury, 2015.

Rambo, S. Spirit and trauma: a theology of remaining. 1st ed. Louisville, Ky: Westminster John Knox Press, 2010.

Rothberg, M. "Decolonizing Trauma Studies: A response." studies in the Novel. vol.40:224-234. 2008.

Said, E.W. Orientalism. 1st Vintage Books ed. New York: Vintage Books, 1979.

Sawyer, J.F.A. Isaiah through the centuries. (Wiley Blackwell Bible commentaries). Hoboken: John Wiley \& Sons, 2018.

Shamai, M. Systemic interventions for collective and national trauma: theory, practice and evaluation. New York, NY: Routledge. 2016.

Spivak, G.C. A critique of postcolonial reason: toward a history of the vanishing present. Cambridge, Mass: Harvard University Press. 1999.

Sugirtharajah, R.S. The postcolonial Biblical reader. R.S. Sugirtharajah (ed.). Malden, MA; Oxford: Blackwell Pub., 2006. https://doi.org/10.1002/9780470775080

Sugirtharajah, R.S. Exploring postcolonial biblical criticism: history, method, practice. Chichester, West Sussex, UK; Malden, MA: Wiley-Blackwell. 2012.

The English Standard Version. Crossway. 2001.

Tutu, D. No future without forgiveness. New York: Doubleday. [Online], Available: http://search.ebscohost.com/login.aspx?direct=true \&scope=site $\& \mathrm{db}=$ nlebk\&db $=$ nlabk\&AN=717553 [2018, August 06]. 1999 .

Visser, I. "Decolonizing trauma theory: retrospect and prospects." MDPI-Humanities. 4:250-265. 2016. https://doi.org/10.3390/h4020250

Ward, A. Postcolonial Traumas Memory, Narrative, Resistance. Hampshire: Palgrave Macmillan.[Online],Available:

http://ezproxy.usherbrooke.ca/login?url=http://dx.doi.org/10.1057/97811375264 34 [2018, August 06]. 2015. https://doi.org/10.1057/9781137526434

Liza Esterhuizen, Research Associate, University of Pretoria, lizahuizen@gmail.com ORCHID: https://orcid.org/0000-0003-2390-5497 